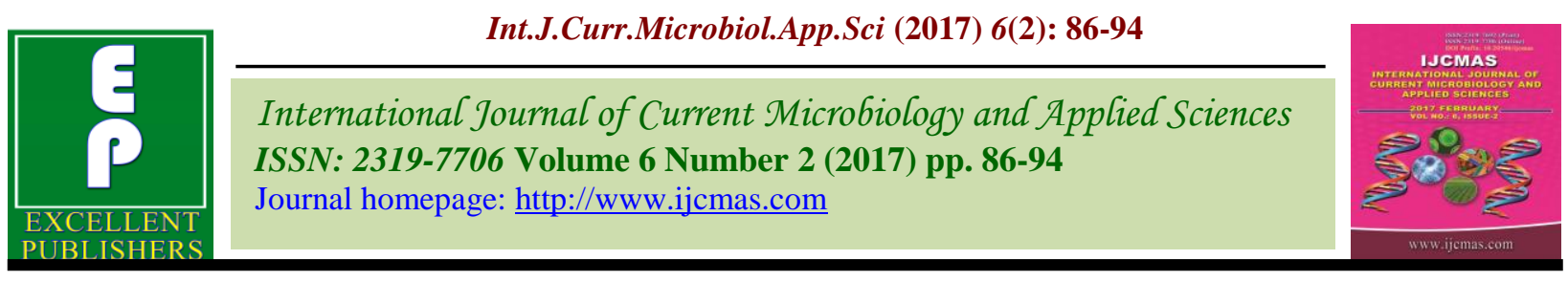

Original Research Article

http://dx.doi.org/10.20546/ijcmas.2017.602.012

\title{
Physiological Responses and In-Vitro Volatile Fatty Acid Production in Cattle
}

\author{
Sunil Kumar*, S.V. Singh and Simson Soren \\ Animal Physiology Division, ICAR- National Dairy Research Institute (NDRI), \\ Karnal, 132001, Haryana, India \\ *Corresponding author
}

\begin{tabular}{|c|c|}
\hline & A B S T R A C T \\
\hline & $\begin{array}{l}\text { The physiological responses, dry matter and water intake of Sahiwal and Karan Fries } \\
\text { (Holstein-Friesian X Tharparkar) heifers were monitored under two feeding regimes i.e. } \\
\text { feeding regime-1 (NRC, 2001) and feeding regime-2 (15\% higher energy than NRC 2001, }\end{array}$ \\
\hline Keywords & $\begin{array}{l}\text { by supplementation of molasses). Six each of healthy heifers of Sahiwal and Karan Fries } \\
\text { (18-24 month) were selected from ICAR-National Dairy Research Institute (ICAR-NDRI), }\end{array}$ \\
\hline $\begin{array}{l}\text { Feeding regimes, } \\
\text { Karan Fries, }\end{array}$ & $\begin{array}{l}\text { Karnal. Before start of actual experiment, the animals were given } 15 \text { days adaptation } \\
\text { period on both the feeding regime. The physiological responses of Sahiwal and Karan }\end{array}$ \\
\hline $\begin{array}{l}\text { Molasses, } \\
\text { Physiological } \\
\text { responses, Sahiwal. }\end{array}$ & $\begin{array}{l}\text { Fries heifers was recorded on } 1^{\text {st }}, 7^{\text {th }}, 14^{\text {th }}, 15^{\text {th }} \text { and } 16^{\text {th }} \text { day of each feeding regime after } \\
\text { adaptation period. The feed offered to the animals and residue left were recorded on daily } \\
\text { basis to find out dry matter intake (DMI) and water intake of all the experimental animals }\end{array}$ \\
\hline Article Info & $\begin{array}{l}\text { was recorded. The mean values of the physiological responses (RR, PR, RT and ST), DMI, } \\
\text { and water intake were significantly }(\mathrm{p}<0.05) \text { higher in Karan Fries than Sahiwal heifers }\end{array}$ \\
\hline $\begin{array}{l}\text { Accepted: } \\
\text { 05 January } 2017 \\
\text { Available Online: } \\
10 \text { February } 2017\end{array}$ & $\begin{array}{l}\text { maintained on both the feeding regimes. However rectal temperature }(\mathrm{R}) \text { was found } \\
\text { significantly }(\mathrm{p}<0.05) \text { higher at feeding regime- } 2 \text { in both the breeds of heifers. The } \\
\text { different proportion of acetate, propionate, and butyrate produced during invitro studies } \\
\text { were found } 70.27,19.38 \text {, and } 10.34 \% \text { for sorghum, } 53.45,37.77 \text { and } 8.78 \% \text { for } \\
\text { concentrate and } 57.36,32.98 \text { and } 9.64 \% \text { for molasses. Based on the results of the study it }\end{array}$ \\
\hline & $\begin{array}{l}\text { can be stated that the feeding of } 15 \% \text { higher energy levels to dairy heifers readjusted their } \\
\text { physiological mechanisms by increasing the physiological responses and propionate } \\
\text { concentration during in-vitro studies. }\end{array}$ \\
\hline
\end{tabular}

\section{Introduction}

Dairy cattle that are raised under extensive conditions and fed on tropical grasses suffer during the lean period, when the production of grass is reduced and a drastic change in the chemical composition of the diet occurs. The sharp increase in energy content and the decrease in the levels of crude fiber increase the digestibility, leading to higher productivity and growth (Gonzalez et al., 2000). The physiological responses to a higher energy intake trigger a series of reactions and consequently allow the organism to adapt in better way to higher energy. These changes have important consequences on animal performance and growth rate (Lima et al., 2011). Ruminants have the ability to adapt to higher energy levels because they can increase their maintenance requirements by increasing the basal metabolic rate. Thyroid hormones play a key role in the basal metabolism, stimulating the cardio-circulatory activity by increasing the heart rate, cardiac output and blood flow and also, the stimulation of neuronal development; and 
increased transmission in neural cells. Energy intake i.e. net energy content of the diet and dry matter intake (DMI) of growing heifers is a primary limitation on the growth rate, the Factors affecting and regulating the feed intake of growing heifers are numerous and complex and span cellular to macro environment levels. Some can be controlled by humans and include animals factor (age, body condition, physiological state etc.), dietary factors (ingredients and nutrient composition of the diet) and climatic factors (temperature, humidity). Therefore the determination of factor affecting DMI and quantification of their effect are important for developing feeding strategies to growing heifers (Hayirli et al., 2002). The in-vitro gas production technique provides a reflection of amounts and proportions of VFA due to close correlation between the stoichiometry of short chain fatty acid (SCFA) within the rumen and the in vitro gas production, (Blummel and Orskov, 1993). The amount of VFA produced in the rumen by the microbial fermentation depends upon feed intake and chemical composition, mainly nature and degradation rate of carbohydrates, (Noziere et al., 2010). Since the information on physiological responses, dry matter intake (DMI) and water intake on high energy diets in Sahiwal and Karan Fries heifers are not measure therefore the present study was designed to investigate the effect of high energy intake on mentioned parameters in Sahiwal and Karan Fries heifers.

\section{Materials and Methods}

The experiment was conducted at Livestock Research Centre (LRC) of ICAR-National Dairy research Institute (NDRI), Karnal, Haryana. The Karnal is situated at an altitude of 250 meters above mean sea level and at $29^{\circ} 42^{\prime} \mathrm{N}$ latitude and $79^{\circ} 59^{\prime} \mathrm{E}$ longitudes. The maximum temperature goes up to $45^{\circ} \mathrm{C}$ in summer and minimum temperature $3.5^{\circ} \mathrm{C}$ to $4^{\circ} \mathrm{C}$ in winter. The annual rainfall is about 700 mm. Six each of healthy Sahiwal and Karan Fries heifers (18-24 month) were selected from the Livestock Research Centre (LRC) of ICAR- National Dairy Research Institute (NDRI), Karnal. The experiment was conducted in the month of NovemberDecember. The experimental animals were maintained as per the standard practices followed at the institute farm. The experimental animals were kept in separate shed throughout the experiment. Experiment was approved by the Institutional Animal Ethics Committee (IAEC) constituted as per the article no.13 of the CPCSEA rules, laid down by Govt. of India. Animals were let loose every week for exercise. The experiment on both group of animals were conducted for 60 days under feeding regime-1 as per NRC (2001) and feeding regime-2 (15\% higher energy level over and above the NRC, 2001 by supplementation of molasses). These animals were maintained on feeding regime-I for 15 days and later on shifted to feeding regime-2 (15\% higher energy level) for next 15 days continuously. The experimental animals were given adaptation period of 15 days prior to actual experiment and in between the both the feeding regime. The concentrate mixture was offered in the morning whereas, the chaffed green sorghum fodder was offered at 11:00 am. Concentrate mixture (CP 19.81\% and TDN 70\%) contained maize 33\%, groundnut cake (oiled) $21 \%$, mustard oil cake (oiled) $12 \%$, wheat bran $20 \%$, deoiled rice bran $11 \%$, mineral mixture $2 \%$ and common salt $1 \%$. The feed offered to the animals and residue left was recorded on daily basis to find out the total dry matter intake (DMI) and $a d$-lib water was given to the animals to find out the total water intake.

The physiological responses (RR, PR, RT and ST) were recorded on $1^{\text {st }}, 7^{\text {th }}, 14^{\text {th }}, 15^{\text {th }}$ and $16^{\text {th }}$ day of each feeding regimes. The 
respiration rate (RR) was taken by counting the inward and outward movement of the flank which was counted as one complete respiration, and expressed as breaths per minute (bpm). Pulse rate (PR) of the animals were counted by observing the pulsation of middle coccygeal artery at the base of the tail. The rectal temperature (RT) was recorded by using clinical thermometer, which was inserted about $5 \mathrm{~cm}$ deep into the rectum of the animals, which remained in contact with the mucous membrane at least 1-2 minutes. The observations were recorded in degree Celsius $\left({ }^{\circ} \mathrm{C}\right)$. The peripheral skin temperature (ST) at different anatomical sites viz, forehead, ears, shoulder region (proximal scapula) and flank regions of the experimental animals, were taken with non-contact telethermometer (Raytek, Model Raynger ST2L, M/s. Surrey Scientific, Surrey, U.K.) by keeping it 2-3 inches away from the desired surface site.

\section{In vitro gas production (IVGP) technique}

The incubations were carried out in $100 \mathrm{ml}$ calibrated glass syringes (Fortuna, Germany) as described by Menke et al., (1979) and Menke and Steingass (1988). The substrate (200 mg) was weighed on a plastic boat with removable stem and was placed into the bottom of the glass syringe ensuring that it did not stick to the sides of the syringe. The piston was lubricated with petroleum jelly and pushed inside the glass syringe. Different levels of phospholipids $(2 \%, 4 \%, 6 \%, 8 \%$ and $10 \%$ ) containing substrate (rouhage:concentrate 60:40) were incubated with rumen liqour in triplicate (three each for blank, respective levels of phospholipid, control) in an oven at $39^{\circ} \pm 0.5^{\circ} \mathrm{C}$ for $24 \mathrm{~h}$.

Rumen liquor was collected from two fistulated cattle maintained on a roughage based diet $(1.0 \mathrm{~kg}$ concentrate mixture in equal proportions at 10.00 am and $4.00 \mathrm{pm}$ and wheat straw ad lib.) before morning feeding into a pre-warmed thermo-flask and brought to the laboratory. The rumen liquor was bubbled with $\mathrm{CO}_{2}$ for about 2 minutes and filtered through 4 layers of muslin cloth. Then reducing solution was added to medium mixture and $\mathrm{CO}_{2}$ was bubbled. The colour of the medium changed from blue over pink to colourless, indicating complete reduction of resazurin. Once the medium became colourless, the required amount of filtered rumen liquor was added to it. Thirty $\mathrm{ml}$ of buffered rumen liquor was pumped with an automatic pipette into each syringe, prewarmed at $39^{\circ} \mathrm{C}$. The syringes were shaken gently and residual air or air bubbles if any was removed and the outlet was closed. The level of piston was recorded and the syringes were placed in an oven $\left(39^{\circ} \pm 0.5^{\circ} \mathrm{C}\right)$. The syringes were shaken every 30 minutes for first $2 \mathrm{~h}$ from the start of the incubation and thereafter every $2 \mathrm{~h}$ up to $10 \mathrm{~h}$ of incubation. Total gas production after $24 \mathrm{~h}$ incubation was recorded. The blank value for gas production (with or without treatments) of incubation was subtracted from the volume of gas produced from the sample to get the net volume of gas produced.

\section{Volatile fatty acids}

Four ml of supernatant from centrifuge tube was transferred to a tube containing $1 \mathrm{ml}$ of $25 \%$ metaphosphoric acid and centrifuged at $3000 \mathrm{rpm}$ for $15 \mathrm{~min}$. The supernatant was transferred to another tube and stored in a freezer $\left(-20^{\circ} \mathrm{C}\right)$ for estimation of VFA. Individual VFA in the rumen fluid samples were determined using Gas chromatograph equipped with flame ionization detector and stainless steel column packed with chromosorb -101 (length 4'; o.d 1/4"; i.d. 3 $\mathrm{mm}$; mesh range 80-100). Analytical conditions for fractionation of VFA were as follows: Injection port temperature, $250^{\circ} \mathrm{C}$; 
column temperature, $190^{\circ} \mathrm{C}$ and detector temperature, $260^{\circ} \mathrm{C}$. The flow rate of carrier gas (nitrogen) was $40 \mathrm{ml} / \mathrm{min}$; hydrogen $30 \mathrm{ml} / \mathrm{min}$; air $300 \mathrm{ml} / \mathrm{min}$. Injection volume was $3 \mu \mathrm{l}$. The injection was performed by means of $10 \mu 1$ Hamilton syringe (Hamilton, Nevada, USA). The concentrations of various VFA (mmol/l) in the standard mixture were acetic acid, 65.07; propionic acid, 20.01 and butyric acid, 8.06. The peaks were identified by comparison of above standards and the response factor obtained using standard VFA mixture for each fraction was used to quantify VFA fractions $(\mathrm{mmol} / \mathrm{l})$ in the sample. The analysis and calculations were performed using Aimil chromatography data system (WINACDS). The amount of VFA produced (mmol) was calculated after deducting the corresponding blank values.

\section{Statistical analysis}

The data analysis was carried out by SAS software, Version (9.1) of the SAS system for Window, Copyright $($ ) (2011) SAS Institute Inc., Cary, NC, USA. The data were analyzed statistically for mean \pm S.E and analysis of variances (ANOVA).

\section{Results and Discussion}

The result of physiological parameters, DMI, and water intake of Sahiwal and Karan Fries heifers during feeding regime- 1 and 2 have been presented in table 1 . The initial and final mean body weight $(\mathrm{kg})$ of Sahiwal and Karan Fries heifers were 167.50 $\pm 4.08,221.83 \pm 15.63$ and $221.50 \pm 7.91,297.00 \pm 13.47$, respectively and significantly $(\mathrm{P}<0.01)$ higher at feeding regime- 2 as compared to feeding regime- 1 in both the breed. The mean values of the physiological responses (RR, PR, RT and ST), DMI, and water intake were significantly $(p<0.05)$ higher in Karan Fries than Sahiwal heifers at both feeding regime. Within the breed physiological responses ( $\mathrm{RR}$ and $\mathrm{PR}$ ), DMI and water intake were higher, whereas ST was lower and RT was significantly $(p<0.05)$ higher at feeding regime-2 as compared to feeding regime- 1 .

The dietary energy intake changes the vital functions, including the pulse rate (beats per minute), respiration rate (breaths per minute bpm) and rectal temperature $\left({ }^{\circ} \mathrm{C}\right)$ in the heifers. The heifers that were fed high energy diets showed prominent increase in the measured parameters. In addition to these changes, the heifers maintained on high energy diets showed more activeness and increased physical activity. While the heifers maintained on basal diets had a RR, PR and RT within the normal range. Mohamad and Abdelatif (2010) observed an increase in the basal metabolism expressed clearly by the increase in heart rate during the high energy diets. Likewise, over energy caused an increased in the respiratory rate above the reference values (Radostits et al., 2007). In case of high energy diets, hyperthermia is most likely due to the increased basal metabolic rate and continued production of thermal body heat (Manish et al., 2010). The overall mean rectal temperature was significantly $(\mathrm{p}<0.05)$ higher in heifers in the energy-rich diets. In comparison to the heart and respiratory rates, the body temperature is much more critical for the survival of the animal, and thus, it is maintained as long as possible. Although there is an increase in the metabolism of many organs (splanchnic tissue) and muscles during energy rich diets, the overall energy expenditure of cattle is even greater in relation to the metabolic weight (Marai et al., 2007). The differences in skin temperatures at different portions were related to diurnal changes and depend upon the heat production of the animals, colour and other properties of the coat and on the solar radiation. Kotrba et al., (2007) had applied same equipment infrared thermography for 
assessing surface temperature and found that elands exposed to cold environmental temperatures had low surface temperatures, similar to cattle which are comparable to our present finding. During the higher energy intake, animal tries to increase the body temperature in order to increase the gradient for heat loss to the environment .This further increases metabolic requirements as per the Newton's law of cooling. During high energy intake hyper metabolic state involves increase in body temperature. This increase in body temperature further increases metabolic rate as per Vant Hoff's rule (Hyder et al., 2013). The pulse rate is an indicator of general metabolic status and in the present study the increase in pulse rate could be due to increase in metabolic rate as a result of high energy diets. Samad et al., (2014) have shown that there is increase in energy expenditure with increased energy intake which is due to increased oxygen consumption by peripheral skeletal muscles. Similarly the increase in respiratory rate as observed in the present study might be due to increased metabolic activity and increased oxygen consumption (Hyder et al., 2013). During feeding regime-1 and 2 there was no significant difference in skin temperature. The value of ST would be higher during feeding regime-2 due to increase in metabolic heat production but the numerical value were slightly lower during feeding regimes-2, this may be probably due to lower ambient temperature. Toda et al. (2002) also reported that positive relationship among environmental temperature and skin temperature in Holstein cows.

The result of the dry matter intake and water intake during present study are in agreement with Montgomery and Baumgardt (1965) who reported that higher energy levels of the diet reduces the DMI due to chemicals produced during fermentation and physiological regulations, which includes chemostatic or thermostatic controls that attempt to maintain a balance in the body. The increasing trend of water intake was observed during feeding regime- 2 as compared to feeding regime- 1 in both the breeds. Saeed et al. (2002) found that feeding of molasses urea block increased the demand for drinking water irrespective of forage type suggested high requirement of drinking water with molasses feeding because it increases the digestibility, oxidation and passage rate of the feed.

\section{Volatile fatty acids (In vitro)}

The result of different proportions of VFAs (acetate, propionate and butyrate) produced during in-vitro study have been presented in Fig.1. During the present study the proportion of acetate, propionate, and butyrate were $70.27 \pm 0.49,19.38 \pm 0.82$ and $10.34 \pm 0.32 \%$ for sorghum, $53.45 \pm 2.78, \quad 37.77 \pm 4.91$ and $8.78 \pm 2.13 \%$ for concentrate and $57.36 \pm 4.07$, $32.98 \pm 0.28$ and $9.64 \pm 3.79 \%$ for molasses and also the proportion of different VFA changed with different feed ingredients and with change in their ratio (Fig. 2). Singh and Mohini (1999) reported the normal molar proportion of acetate, propionate and butyrate in cattle as $65.85 \pm 1.32,24.33 \pm 0.99$ and $9.97 \pm 0.86$ respectively.

Raun et al., (1976) also reported a shift towards more propionate after feeding the rumensin led to decrease in both acetate and butyrate. Blummel and Orskov (1993) found that in vitro gas production technique provides a reflection of amounts and proportions of VFA due to close correlation between the stoichiometry of short chain fatty acid (SCFA) within the rumen and the in vitro gas production. 
Table.1 Physiological parameters, DMI and water intake in Sahiwal and Karan Fries heifers under two different feeding regimes

\begin{tabular}{ccccc}
\hline & \multicolumn{2}{c}{ Sahiwal heifers } & \multicolumn{2}{c}{ Karan fries heifers } \\
\hline Parameters & Feed-1 & Feed-2 & Feed-1 & Feed-2 \\
RR(bpm) & $22.00 \pm 0.45^{\mathrm{a}}$ & $23.10 \pm 0.39^{\mathrm{a}}$ & $25.76 \pm 0.49^{\mathrm{b}}$ & $26.36 \pm 0.43^{\mathrm{b}}$ \\
PR (BPM) & $68.60 \pm 1.04^{\mathrm{a}}$ & $69.23 \pm 0.74^{\mathrm{a}}$ & $73.13 \pm 1.14^{\mathrm{b}}$ & $74.43 \pm 0.63^{\mathrm{b}}$ \\
RT( $\left.{ }^{\mathbf{o}} \mathbf{C}\right)$ & $38.33 \pm 0.08^{\mathrm{a}}$ & $38.60 \pm 0.04^{\mathrm{b}}$ & $38.64 \pm 0.04^{\mathrm{c}}$ & $38.88 \pm 0.07^{\mathrm{d}}$ \\
ST ( $\mathbf{0}$ C) & $30.36 \pm 0.83^{\mathrm{a}}$ & $30.13 \pm 0.81^{\mathrm{a}}$ & $33.63 \pm 0.58^{\mathrm{b}}$ & $33.33 \pm 0.56^{\mathrm{b}}$ \\
DMI (Kg/day) & $5.92 \pm 1.68^{\mathrm{a}}$ & $5.54 \pm 1.03^{\mathrm{a}}$ & $6.61 \pm 1.67^{\mathrm{b}}$ & $6.41 \pm 1.10^{\mathrm{b}}$ \\
WI (Lit/day) & $9.01 \pm 0.35^{\mathrm{a}}$ & $9.57 \pm 0.40^{\mathrm{a}}$ & $13.93 \pm 0.58^{\mathrm{b}}$ & $15.76 \pm 0.65^{\mathrm{b}}$ \\
\hline
\end{tabular}

$\mathrm{RR}=$ Respiration rate; $\mathrm{PR}=$ Pulse rate; $\mathrm{RT}=$ Rectal temperature; $\mathrm{ST}=$ Skin temperature; DMI= Dry matter intake;

$\mathrm{WI}=$ Water intake; $\mathrm{bpm}=$ breaths $/$ minute; $\mathrm{BPM}=$ beats $/ \mathrm{min}$

Means showing different superscripts in row differs significantly at $5 \%(\mathrm{P}<0.05)$

Fig.1 In-Vitro VFA production of different feed ingredients

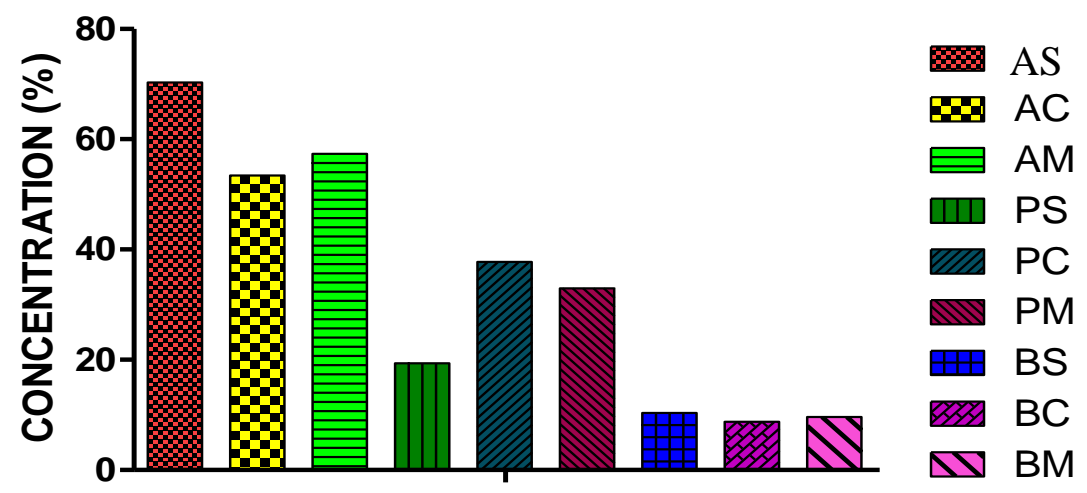

Fig.2 In-Vitro VFA production of feed ingredients with different combination (Ratio)

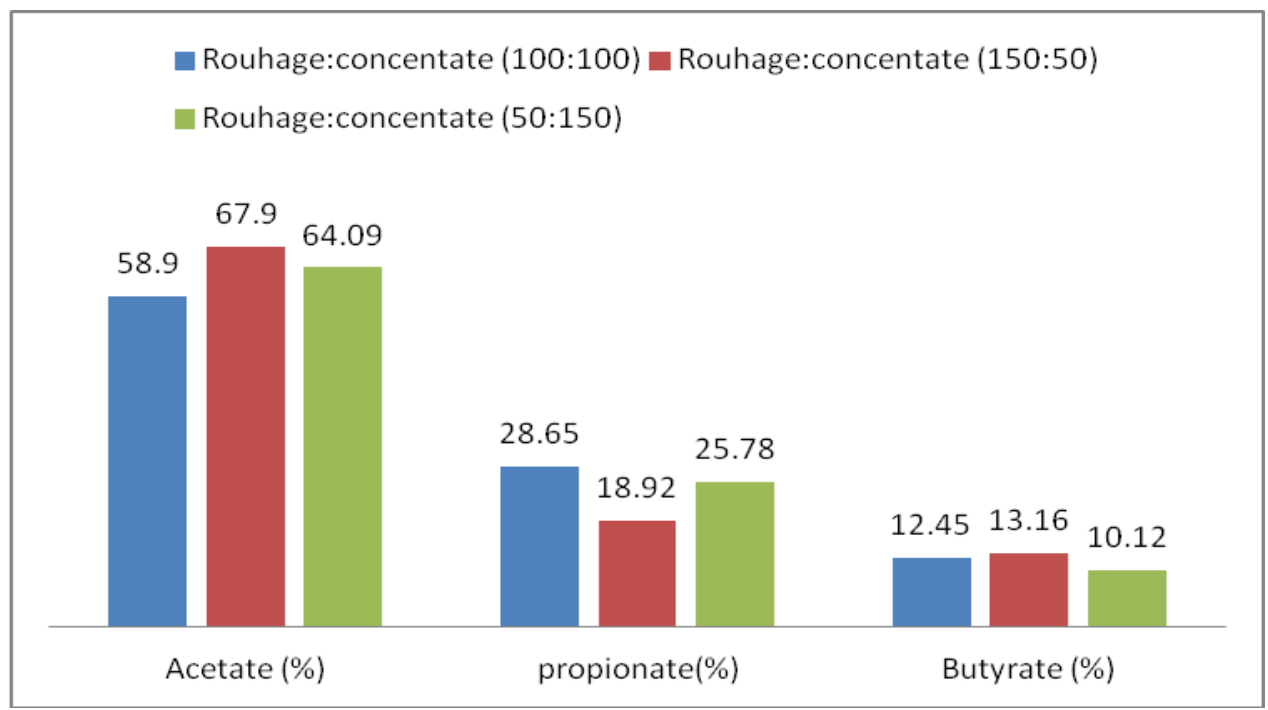


Trenkle (1970) also found that when the two groups of sheep fed grain, had significantly $(\mathrm{P}<0.01)$ less propionate than the Sheep fed only hay at each level of energy consumption, also the highest proportion of propionate and butyrate occurred in animals during the period of unlimited intake of the $30 \%$ hay diet. Fernadez et al., (1980) found the mean values for molar proportion of VFA i.e acetate $(76.9 \pm 1.1)$ and $(68.5 \pm 1.3)$, propionate (17.6 $\pm 1.2)$ and $(20.3 \pm 0.6)$, butyrate $(5.1 \pm 0.9)$ and $(9.8 \pm 0.9)$ in rumen fluid collected from bulls fed sugarcane and molasses/urea with or without the additives respectively. The result of the present study is in agreement with Phesatcha and Wanapat (2016) who reported that supplementation of molasses at concentration of $2.0 \%$ resulted in a higher $(\mathrm{p}<0.05)$ proportion of propionic acid $(34.4$ mole/100 mole) and a lower $(\mathrm{p}<0.01)$ proportion of acetic acid which was highest in the control.

Based on the results of the study it can be concluded that the feeding of $15 \%$ higher energy intake to dairy heifers readjust its physiological mechanisms by increasing the physiological responses and propionate percentage during in-vitro studies. This adaptive strategy may pave the way for the judicious partition of dietary energy for maintaining vital physiological functions, dry matter and water intake.

\section{Acknowledgement}

The authors express sincere thanks to the Director, ICAR-NDRI, Karnal for providing all necessary facilities for conducting research work. The authors acknowledge the NICRA project for financial help to carry out this research work.

\section{References}

Blummer, M. and Orskov, E.R. 1993. Comparison of in-vitro gas production and nylon bag degradability of roughages in predicting feed intake in cattle. Anim. Feed Sci. Tech., 40: 109119.

Fernandez, A., Rowe J.B. and Preston, T.R. 1980. Effect of a methane inhibitor on growth performance and rumen VFA of steers fed sugarcane and molasses. Trop. Anim. Prod., 5: 2.

González, F.H., Barcellos, J., Patiño H.O. and Ribeiro, L.A. 2000. Perfil metabólico em ruminantes. Seu uso em nutrição e doenças nutricionais. Porto Alegre: Editora UFRGS, 106.

Hayirli, A., Grummer, R.R., Nordhein E.V. and Crump, P.M. 2002. Animal and dietary factor affecting feed intake during the prefresh transition period in Holstein. J. Dairy Sci., 85(12): 34303443.

Hyder, I., Ramesh, K., Sharma, S., Uniyal, S., Yadav, V.P., Panda R.P. and Sarkar, M. 2013. Effect of different dietary energy levels on physio-biochemical, endocrine changes and mRNA expression profile of leptin in goat (Capra hircus). Livestc. Sci., 152(1): 63-73.

Kotrba, R., Knizkova, I., Kunc P. and Bartos, L. 2007. Comparison between the coat temperature of the eland and dairy cattle by infrared thermography. J.Therm. Biol., 32(6): 355-359.

Lima, A.S., Sucupira M.C.A. and Ortolani, E.L. 2011. Bovinos submetidos a dietas deficientes em energia por longo período: desempenho animal e sua relação com os teores de $\mathrm{T}_{3}$ e IGF-1. Braz. J. Vet. Res. Anim. Sci., 48(1): 1926.

Manish, K., Jindal, R., Nayyar S. and Singla, M. 2010. Physiological and biochemical responses in Beetle goats during summer season. Ind. J. Small Rum., 16: 255-57.

Marai, I.F.M., El-Darawany, A.A., Fadiel A. and Abdel-Hafez, M.A.M. 2007. 
Physiological traits as affected by heat stress in sheep: a review. Small Rum. Res., 71: 1-12.

Menke, K.H. and Steingass, H. 1998. Estimation of the energetic feed value obtained by chemical analysis and in vitro gas production using rumen fluid. Anim. Res. Dev., 28: 7- 55.

Menke, K.H., Raab, L., Salewski, A., Steingass, H., Fritz D. and Schneider, W. 1979. The estimation of the digestibility and metabolizable energy content of ruminant feedingstuffs from the gas production when they are incubated with rumen liquor in vitro. $J$. Agric. Sci., (Camb)., 93: 217-222.

Mohamad, S.S. and Abdelatif. 2010. Effect of feeding and season on thermoregulation and semen characteristics in desert rams. Global Vet., 4: 207-215.

Montgomery, M.J. and Baumgardt, B.R. 1965. Regulation of food intake in ruminants. Pelleted rations varying in energy concentration. J. Dairy sci., 48(5): 569-574.

Noziere, P., Ortigues-Marty, I., Loncke C. and Sauvant, D. 2010. Carbohydrate quantitative digestion and absorption in ruminants: from feed starch and fibre to nutrients available for tissues. Animal, 4: 1057-1074.

Phesatcha, K. and Wanapat, M. 2015. Improvement of Leucaena silage nutritive value and in vitro ruminal fermentation by molasses and urea supplementation. Asian-Aus. J. Anim. Sci., DOI, 10.

Radostits, O.M., Gay, C.C., Hinchcliff K.W. and Constable, P.D. 2007. A textbook of the diseases of the Cattle, Horses, Sheep, Pigs and Goats. Veterinary medicine. 10th ed. London, UK: Saunders. 2045- 2050.

Raun, A.P., Cooley, C.O., Potter, E.L., Rathmacher R.P. and Richardson, L.F. 1976. Effect of monensin and feed efficiency of feed lot cattle. J. Anim. Sci., 43: 670-677.

Saeed, I., Siddiqui M.M. and Habib, G. 2002. Associative effect of molasses-urea block and forage quality on nutrient digestion and nitrogen retention in sheep. Pak. Vet. J., 22(1): 11-16.

Samad, H.A., Latheef, S.K., Anurag K.S. and Maurya, V.P. 2014. Effect of nutritional stress on physiological responses of non-descript Indian buck (Capra hircus). Vet. Sci., 3(7): 2277-2280.

Singh, G.P. and Mohini, M. 1999. Effect of different levels of rumensin in diet on rumen fermentation, nutrient digestibility and methane production in cattle. Asian-Aus. J. Anim. Sci., 12(8): 1215-1221.

Toda, K., Nakai, F., Leki, H., Fuzioka, K., Watanbe, H., Iuchi T. and Tereda, F. 2002. Effects of Effective Temperature on milk yield of Holstein cows in hot and humid environments. Nihon Chikusan Gakkaino. 73(1): 63-100.

Trenkle, A. 1970. Effects of short-chain fatty acids, feeding, fasting and type of diet on plasma insulin levels in sheep. Journal paper no. J-6531 of the Iowa Agriculture and Home Economics Experiment Station, Ames.Project no. 1208.

\section{How to cite this article:}

Sunil Kumar, S.V. Singh and Simson Soren. 2017. Physiological Responses and In-Vitro Volatile Fatty Acid Production in Cattle. Int.J.Curr.Microbiol.App.Sci. 6(2): 86-94. doi: http://dx.doi.org/10.20546/ijcmas.2017.602.012 


\section{Preparation of solutions}

Composition of Micromineral solution $^{\mathrm{a}}$

$\begin{array}{lc}\mathrm{CaCl}_{2} \cdot 2 \mathrm{H}_{2} \mathrm{O} & 13.2 \mathrm{~g} \\ \mathrm{MnCl}_{2} \cdot 4 \mathrm{H}_{2} \mathrm{O} & 10.0 \mathrm{~g} \\ \mathrm{CoCl}_{2} \cdot 6 \mathrm{H}_{2} \mathrm{O} & 1.0 \mathrm{~g} \\ \mathrm{FeCl}_{3} \cdot 6 \mathrm{H}_{2} \mathrm{O} & 8.0 \mathrm{~g}\end{array}$

Dissolved in $100 \mathrm{ml}$ of water.

Composition of rumen buffer solution ${ }^{\mathrm{b}}$

$\mathrm{NH}_{4} \mathrm{HCO}_{3} \quad 4.0 \mathrm{~g}$

$\mathrm{NaHCO}_{3} \quad 35.0$

Dissolved in $1000 \mathrm{ml}$ of water.

Composition of Macro mineral solution $^{\mathrm{c}}$

$\mathrm{Na}_{2} \mathrm{HPO}_{4}$ anhydrous $5.70 \mathrm{~g}$

$\mathrm{KH}_{2} \mathrm{PO}_{4}$ anhydrous $\quad 6.20 \mathrm{~g}$

$\mathrm{MgSO}_{4} \cdot 7 \mathrm{H}_{2} \mathrm{O} \quad 0.60 \mathrm{~g}$

Dissolved in $1000 \mathrm{ml}$ of water

Composition of resazurin solution ${ }^{\mathrm{d}}$

Dissolved $100 \mathrm{mg}$ resazurin in $100 \mathrm{ml}$ distilled water

Composition of Reducing solution

$\begin{array}{lc}1 \mathrm{~N} \mathrm{NaOH} & 2.4 \mathrm{ml} \\ \mathrm{Na}_{2} \mathrm{~S} .7 \mathrm{H}_{2} \mathrm{O} & 330 \mathrm{mg} \\ \text { Distilled water } & 55 \mathrm{ml}\end{array}$

Composition of incubation medium

Distilled water $\quad 550 \mathrm{ml}$

Micromineral solution $^{\mathrm{a}} \quad 0.15 \mathrm{ml}$

Rumen buffer solution $^{\mathrm{b}} \quad 275 \mathrm{ml}$

Macromineral solution $^{\mathrm{c}} \quad 275 \mathrm{ml}$

Resazurin solution $\quad 1.45 \mathrm{ml}$

Added $500 \mathrm{ml}$ of strained rumen liquor to the above incubation medium. 